\title{
FORMATION OF METASTABLE VATERITE CRYSTALS IN A POLYMER MATRIX BY GASEOUS DIFFUSION
}

\author{
MICHAEL W. PITCHER ${ }^{A^{*}}$, ABDOLLAH NESHAT ${ }^{B}$ AND SEMIH SEYYIDOĞLU ${ }^{A}$
}

\author{
${ }^{a}$ Department of Chemistry, Middle East Technical University, 06531 Ankara, Turkey \\ ${ }^{b}$ Current address: Department of Chemistry, Bowman-Oddy Laboratories, MS 602, The University of Toledo, 2801 W. Bancroft St, Toledo, OH 43606, USA
}

(Received: 24 May 2007 - Accepted: 27 February 2008)

\begin{abstract}
A composite consisting of a polymer and calcium carbonate has been synthesized by allowing carbon dioxide to diffuse into a poly(ethylene oxide) film containing a source of calcium ions. The X-ray pattern of the synthetic composite material shows that the least thermodynamically stable polymorph of calcium carbonate, vaterite is the mineral phase which is formed, rather than the most thermodynamically stable calcite phase. This effect has been seen in other reports of crystallization of inorganic phases which have been mediated by a polymer matrix and/or other organic moieties. In this paper, some possible explanations are presented which may help explain this phenomenon.
\end{abstract}

\section{INTRODUCTION}

The crystallization behavior of calcium carbonate $\left(\mathrm{CaCO}_{3}\right)$ is important for multiple reasons. Although it is not the most technologically important material, $\mathrm{CaCO}_{3}$ is an unwanted problem in many industries, including the paper industry ${ }^{1}$ and in water treatment ${ }^{2}$. Recent work is also showing that it can indeed be a beneficial component in the formation of polymer ${ }^{3}$ and plastic/rubber ${ }^{4} \mathrm{CaCO}_{3}$ nanocomposites with improved properties. Perhaps the most important reason is trying to understand how living organisms control the crystallization of $\mathrm{CaCO}_{3}$ in various skeletal parts; such an understanding might provide access to new synthetic strategies and novel or functional materials, as well providing insight into the biomineralization process ${ }^{5,6}$. One approach to mimicking the natural biomineralization process and/or attempting to control or affect the crystallization behavior of $\mathrm{CaCO}_{3}$ is to carry out the synthesis in the presence of a polymer or polymeric additive, which may or may not be biological in origin. In the last year nearly one hundred English journal papers have been published on this topic alone; in ten of these cases ${ }^{7-16}$, vaterite, the least thermodynamically stable polymorph of $\mathrm{CaCO}_{3}$ is formed, rather than the most thermodynamically stable form, calcite. This is analogous to the phase selection seen in biomineralized sea-shells and other structural materials.

In this paper we describe a new method for synthesizing vaterite, by allowing carbon dioxide $\left(\mathrm{CO}_{2}\right)$ to diffuse into a polymer film containing a source of calcium ions (calcium chloride) and discuss possible reasons why the metastable vaterite is produced instead of calcite. The polymer chosen was poly(ethylene oxide) as it has been previously been demonstrated that there is strong interaction between this polymer and growing inorganic salts causing control of phase and/or morphology 17,18 .

\section{EXPERIMENTAL}

Poly(ethylene oxide) (PEO, $\left.\mathrm{M}_{\mathrm{w}}=200,000\right)$ and calcium chloride $\left(\mathrm{CaCl}_{2} 2 \mathrm{H}_{2} \mathrm{O}\right)$ were purchased from Aldrich and used as received. Composite $\mathrm{CaCO}_{3} / \mathrm{PEO}$ films were prepared by casting a film of $\mathrm{PEO} / \mathrm{CaCl}_{2}$ from solutions of $\mathrm{PEO}$ and $\mathrm{CaCl}_{2} \cdot 2 \mathrm{H}_{2} \mathrm{O}$ (9:1 ratio by weight to yield a total weight of 0.50 g) dissolved in $10 \mathrm{~mL}$ distilled water. The solution was poured onto a glass microscope slide until no more solution could be applied. The solvent was then allowed to evaporate. The film was removed from the glass slide prior to the reaction using a razor blade or scalpel. The thickness of the film was between 0.1 and $0.2 \mathrm{~mm}$. The film was then placed in dessicator and suspended above a beaker containing solid ammonium carbonate $\left(\left(\mathrm{NH}_{4}\right)_{2} \mathrm{CO}_{3}\right)$ as the source of $\mathrm{CO}_{2}$. After twenty four hours the films were removed and analyzed by optical microscopy and X-ray diffraction (XRD). In addition to this a beaker of $\mathrm{CaCl}_{2}$ solution was also placed in the dessicator with $\left(\mathrm{NH}_{4}\right)_{2} \mathrm{CO}_{3}$, the white precipitate that begins to form almost immediately was filtered, dried and the $\mathrm{X}$-ray pattern also taken. This experiment acted as a control.

$\mathrm{X}$-ray analysis of the compounds was performed using a Rigaku Diffractometer Miniflex equipped with $\mathrm{CuK} \alpha((30 \mathrm{kV}, 15 \mathrm{~mA}, \lambda=1.54051$ $\AA$ ) radiation at room temperature. Data was collected in continuous scanning mode with steps of $0.05^{\circ}(2 \theta)$ with an angular range from $2 \theta=10$ to $70^{\circ}$. The divergence slit was variable, and the scattering and receiving slits were 4.2 deg. and $0.3 \mathrm{~mm}$, respectively. X-ray patterns were obtained of the starting $\mathrm{CaCl}_{2} 2 \mathrm{H}_{2} \mathrm{O}$ powder, a pure $\mathrm{PEO}$ film, a $\mathrm{PEO} / \mathrm{CaCl}_{2}$ film, the final $\mathrm{PEO} /$ $\mathrm{CaCO}_{3}$ film and the white precipitate from the control experiment. Powder
X-ray diffraction (XRD) data of the control experiment was collected on a PANalytical X'Pert Pro using CuK $\alpha$ radiation again between $2 \theta=10$ to $70^{\circ}$. The sample was contained in an aluminum sample holder. Optical microscopy was done using a Leica CME.

\section{RESULTS AND DISCUSSION}

The X-ray patterns of the samples are presented in Fig. 1. It should be noted that there is no evidence of crystallization on the polymer surface, so crystallization has to have occurred within the polymer film; this was deduced by optical microscopy studies.

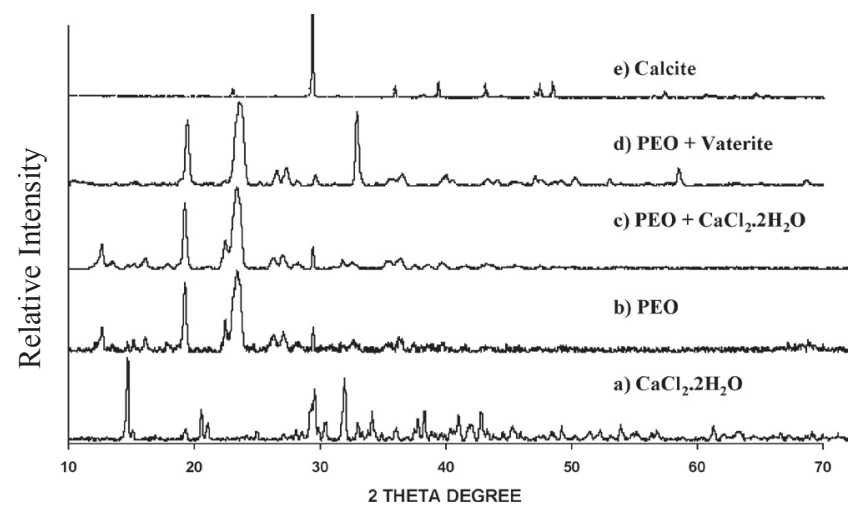

Fig. 1. X-ray powder diffraction patterns of a) calcium chloride starting material, b) a poly(ethylene oxide) film, c) a poly(ethylene oxide) and calcium chloride film , d) $\mathrm{CaCO}_{3}$ (vaterite) grown in a poly(ethylene oxide) film, e) $\mathrm{CaCO}_{3}$ (calcite) precipitated by exposure of a calcium chloride solution to a source of carbon dioxide.

By comparing patterns a with $\mathrm{b}$ and $\mathrm{c}$, it is clear that the $\mathrm{PEO}$ reflections dominate the pattern of the $\mathrm{PEO} / \mathrm{CaCl}_{2}$ starting material. Upon subsequent exposure to $\mathrm{CO}_{2}$ however there is a distinct change in the pattern (d). Analysis of pattern $\mathrm{d}$ is presented in Table 1 . 
Table 1. X-ray powder diffraction analysis of pattern d).

\begin{tabular}{|c|c|c|c|c|c|c|}
\hline Pattern d & & Vaterite & & PEO & & \\
\hline $\mathbf{d}_{\text {obs }}$ & $\mathbf{I}_{\mathbf{0}}$ & $\mathbf{d}_{\text {obs }}$ & $\mathbf{I}_{\mathbf{0}}$ & $\mathbf{d}_{\text {obs }}$ & $\mathbf{I}_{\mathbf{0}}$ & Identification \\
\hline 4.5715 & 78 & & & 4.6187 & 87 & PEO \\
\hline 3.9744 & 6 & & & 3.9656 & 41 & PEO \\
\hline 3.7824 & 100 & 3.713 & 8 & 3.8144 & 100 & PEO \\
\hline 3.5379 & 4 & 3.576 & 42 & & & Vaterite \\
\hline 3.3606 & 19 & & & 3.3921 & 23 & PEO \\
\hline 3.2698 & 22 & 3.294 & 74 & & & Vaterite \\
\hline 2.8687 & 3 & & & 2.8959 & 8 & PEO \\
\hline 2.7200 & 88 & 2.733 & 100 & & & Vaterite \\
\hline 2.4629 & 14 & & & 2.4793 & 18 & PEO \\
\hline 2.2548 & 12 & 2.279 & 2 & 2.2878 & 8 & PEO \\
\hline 2.2281 & 7 & 2.218 & 17 & & & Vaterite \\
\hline 2.0878 & 8 & & & 2.0786 & 8 & PEO \\
\hline 2.0517 & 7 & 2.064 & 50 & & & Vaterite \\
\hline 1.8521 & 6 & 1.856 & 32 & & & Vaterite \\
\hline 1.8158 & 10 & 1.824 & 41 & & & Vaterite \\
\hline 1.7278 & 9 & 1.749 & 10 & & & Vaterite \\
\hline 1.5776 & 22 & 1.569 & 1 & & & Vaterite \\
\hline 1.3668 & 7 & 1.367 & 9 & & & Vaterite \\
\hline
\end{tabular}

The figure shows that, again, the pattern is dominated by the PEO reflections, however there are new reflections, which are neither the $\mathrm{CaCl}_{2}$ starting material nor calcite (control - pattern e (note: the small peaks at $2 \theta$ $=38,45$ and 65 belong to the aluminum sample holder)) but which were determined to be vaterite (ICDD Card No: 74-1867) (Table 1).

The question is why is the metastable vaterite formed in the presence of the polymer, but calcite in the absence of PEO? There are reports where crystallizing an inorganic phase inside a polymer has produced high-pressure phases of cadmium sulfide ${ }^{19}$, novel and high-pressure phases of lead sulfide ${ }^{20}$ and in one instance the formation of crystalline lithium niobate without the application of heat ${ }^{21}$. It is suggested that "the density or rigidity of the matrix regulates the phase of the crystals that form, predominantly by a "solid state" densification effect, whereby the solid state of the polymer matrix acts to confine growth spatially such that the growing crystal is forced to adopt a more dense form than it would in solution growth, resulting in the formation of high-pressure phases" 22.

In this work, however, this is unlikely to be the explanation for vaterite formation, for two reasons. Firstly, vaterite is not the most dense form of $\mathrm{CaCO}_{3}$ (aragonite > calcite > vaterite) and secondly, vaterite is not, to the best of our knowledge, the high-pressure phase of $\mathrm{CaCO}_{3}$; although to date, we have only been able to find one phase diagram of $\mathrm{CaCO}_{3}{ }^{23}$ in existence. So an alternative explanation has to be found; one theory that is often seen in literature reports when vaterite is formed is that there is some kind of stabilization of the vaterite phase which stops it transforming to calcite, or growth inhibition of the stable calcite ${ }^{24}$. This theory works very well but still does not explain why vaterite is formed in the first instance. A possible, perhaps more convincing argument is that there is some effect on the surface energy of the growing crystal, which affects the phase into which it first crystallizes. The pioneering work of Navrotsky and co-workers has shown that the different polymorphs of various inorganic minerals, including alumina ${ }^{25}$, titania ${ }^{26}$ and zirconia ${ }^{27}$ have different surface energies, which in turn is a key contributing element to the stability of that form. Also the elegant work by De Yoreo, Orme and co-workers has shown that, specifically in the case of $\mathrm{CaCO}_{3}$, the binding of amino acids (the building block of biological polymers; polypeptides) changes the free energies of the step edges of calcite crystal thus altering "the energy landscape" ${ }^{28}$. To prove or disprove such a theory is beyond the scope of this work, but one aspect remains surely certain and that is that the energetics of crystal growth in a polymer are likely to be very different than crystal growth by precipitation or other routes. Our studies continue in this area by looking at the stability of the vaterite formed in the polymer films and attempting to follow the crystallization/crystal growth by transmission electron microscopy.

\section{CONCLUSIONS}

Vaterite, the least thermodynamically stable form of $\mathrm{CaCO}_{3}$ has been formed by a new method carrying out crystallization within a polymer film. This formation of a metastable or thermodynamically unfavorable phase has been seen by other workers with a variety of different inorganic minerals; possibly indicating that such a methodology might be used for the synthesis of other technologically important materials e.g. cubic boron nitride under similarly mild conditions.

\section{ACKNOWLEDGEMENTS}

The authors would like to thank John Neil and Sergey Ushakov of the Thermochemistry Facility at the University of California, Davis for help in retrieving reference 23 and Cora Lind at the University of Toledo for obtaining the X-ray pattern of the control experiment (calcite).

\section{REFERENCES}

1. A. Loraine, P.E. Huchler, Paper Technology 47, 23, (2006).

2. D. Hasson, R. Semiat, M. Ilevicky, D. Damiano, A. Sher, Proceedings - Water Quality Technology Conference and Exhibition (2004).

3. X. Lu, T. Liu, Polymer Nanocomposites 412, (2006).

4. A. Chakravarty, Rubber India 57, 23, (2005).

5. S. Mann Biomineralization: Principles and Concepts in Bioinorganic Materials Chemistry, Oxford University Press, Oxford, 2002.

6. A-W. Xu, Y. Ma, H. Cölfen, J. Mater. Chem. 17, 415, (2007).

7. K. Wikander, P. Kjellin, K. Holmberg, Nord. Pulp Paper Res. J. 21, 286, (2006).

8. A.Sugawara, A. Oichi, H. Suzuki, Y. Shigesato, T. Kogure, T. Kato, J. Polym. Sci. Polym. Chem. 44, 5153, (2006).

9. K. Naka, S-C. Huang, Y. Chujo, Langmuir 22, 7760, (2006).

10. X-H. Guo, S-H. Yu, G-B. Cai, Angew. Chem., Int. Ed. Engl. 45, 3977, (2006).

11. Y-X. Gao, S-H. Yu, X-H. Guo, Langmuir 22, 6125, (2006).

12. A. Kotachi, T. Miura, H. Imai, Cryst. Growth Des. 6, 1636, (2006)

13. K. Ichikawa, N. Shimomura, B. Chem. Soc. Jpn 79, 580, (2006).

14. N. Loges, K. Graf, L. Nasdala, W. Tremel, Langmuir 22, 3073, (2006).

15. H. Wakayama, S.R. Hall, Y. Fukushima, S. Mann, Ind. Eng. Chem. Res. 45, 3332, (2006).

16. H. Shinya, O. Kousaku, Y. Hiroyuki, Macromol. Biosci. 6, 228, (2006).

17. S. Radhakrishnan, J.M. Schultz, J. Cryst. Growth 116, 378, (1992).

18. S. Radhakrishnan, D.R. Saini, J. Cryst. Growth 129, 191, (1993).

19. J. Lin, E. Cates, P.A. Bianconi, J. Am. Chem. Soc. 116, 4738, (1994).

20. M.W. Pitcher, E. Cates, L. Raboin, P.A. Bianconi, Chem. Mater. 12, 1738 (2000).

21. M.W. Pitcher, Y. He, P.A. Bianconi, Mater. Chem. Phys. 90, 57, (2005).

22. E. Cates, M.W. Pitcher, P.A. Bianconi, Mater. Chem. Phys. 94, 13, (2005).

23. A.F. Bol'shakov, L.V. Abramova, B.V. Abalduev, J. Appl. Chem. USSR (Engl. Transl.) 49, 2076, (1976).

24. I.W. Kim, R.E. Robertson, R. Zand, Cryst. Growth Des. 5, 513, (2005).

25. J.M. McHale, A. Auroux, A.J. Perrotta, A. Navrotsky, Science 277, 788, (1997).

26. M. R. Ranade, A. Navrotsky, H. Z. Zhang, J. F. Banfield, S. H. Elder, A. Zaban, P. H. Borse, S. K. Kulkarni, G. S. Doran, H. J. Whitfield, P. Natl Acad. Sci. USA 99, 6476, (2002).

27. M.W. Pitcher, S.V. Ushakov, A. Navrotsky, B.F. Woodfield, G. Li, J. Boerio-Goates, B.M. Tissue, J. Amer. Ceram. Soc. 88, 160 (2005).

28. C.A. Orme, A. Noy, A. Wierzbicki, M.T. McBride, M. Grantham, H.H. Teng, P.M. Dove, J.J. DeYoreo, Nature 411, 775, (2001). 